CORRIGENDUM OPEN

\title{
The gut microbiota: a major player in the toxicity of environmental pollutants?
}

Sandrine P Claus, Hervé Guillou and Sandrine Ellero-Simatos

npj Biofilms and Microbiomes (2017) 3, 17001; doi:10.1038/npjbiofilms.2017.1; published online 22 June 2017

Correction to: npj Biofilms and Microbiomes (2016) 2, 16003; doi:10.1038/npjbiofilms.2016.3; published online 4 May 2016

In the Supplementary Information File originally published with this Article, the tracked changes were visible within the document. This error has now been corrected in the Supplementary Information that now accompanies the Article.

A correction has been published and is appended to both the HTML and PDF versions of this paper. The error has been fixed in the paper. (i) This work is licensed under a Creative Commons Attribution 4.0 International License. The images or other third party material in this article are included in the article's Creative Commons license, unless indicated otherwise in the credit line; if the material is not included under the Creative Commons license, users will need to obtain permission from the license holder to reproduce the material. To view a copy of this license, visit http://creativecommons.org/licenses/ by $/ 4.0 /$

(c) The Author(s) 2017 